\title{
Working
}

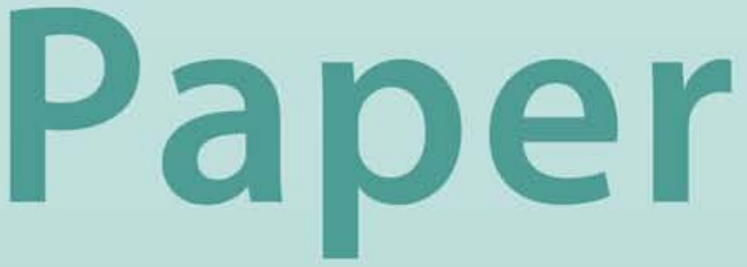




\section{Corporate Balance Sheet Restructuring and Investment in the Euro Area}

Albert Jaeger 


\title{
IMF Working Paper
}

\author{
European I Department
}

Corporate Balance Sheet Restructuring and Investment in the Euro Area

\author{
Prepared by Albert Jaeger ${ }^{1}$
}

Authorized for distribution by Bankim Chadha

June 2003

\begin{abstract}
The views expressed in this Working Paper are those of the author(s) and do not necessarily represent those of the IMF or IMF policy. Working Papers describe rescarch in progress by the author(s) and are published to elicit comments and to further debate.
\end{abstract}

The recent boom-bust cycle in the euro area's equity valuations has left nonfinancial corporations saddled with a legacy of high debt or leverage. Models of corporate investment behavior based on imperfect capital markets predict that highly leveraged balance sheets can act as a brake on investment spending. The paper's empirical analysis suggests that leverage effects on corporate investment can be substantial and persistent, particularly if leverage exceeds threshold values.

JEL Classification Numbers:G31, G32, E32, and E37

Keywords: Corporate investment and financing, business cycle, forecasting.

Author's E-Mail Address: Ajaeger@imf.org

\footnotetext{
${ }^{1}$ I would like to thank, without implicating, Luis Catão, Bankim Chadha, Michael Deppler, and Mark Stone. Helpful comments by staff at the European Commission and the European Central Bank on an earlier version of this paper-presented during the December 2002 IMF staff visit to EU institutions-are also gratefully acknowledged.
} 


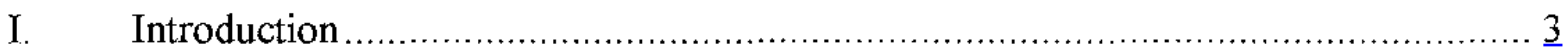

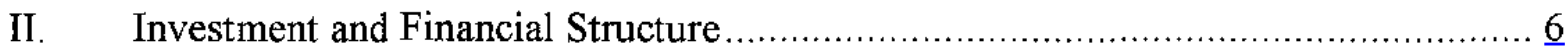

III. The Euro Area's Corporate Boom-Bust Cycle: Stylized Facts ....................... $\underline{8}$

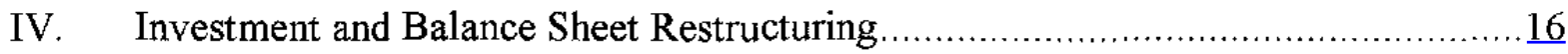

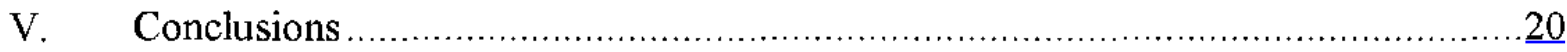

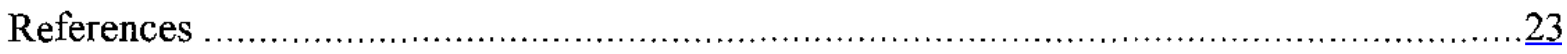

Tables

1. Euro Area: Investment and Financing of Nonfinancial Corporations,

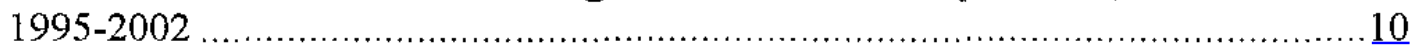

2. Germany: Investment and Financing of Nonfinancial Corporations,

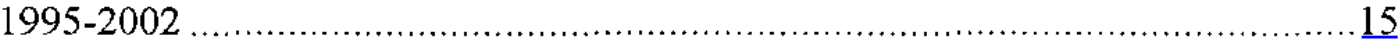

3. Germany and United States: Corporate Investment and Leverage, 1971-2002 ......19

Figures

1. Valuations of Equity of Nonfinancial Corporations in Euro Area

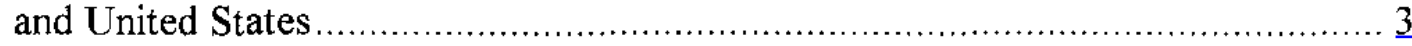

2. Corporate Investment and Financial Structure ........................................ $\underline{6}$

3. Euro Area: Investment and Financing of Nonfinancial Corporations,

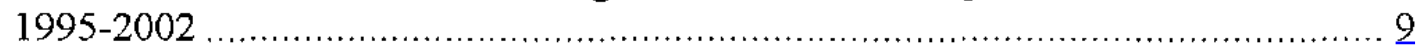

4. Euro Area and United States: Investment and Financing of Nonfinancial

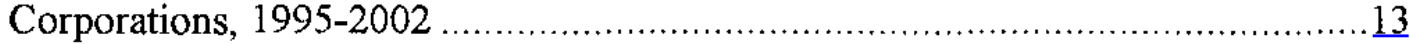

5. Germany and Euro Area Excluding Germany: Investment and Financing of Nonfinancial Corporations, 1995-2002 …................................................ 14

6. Germany and United States: Corporate Investment and Leverage, 1971-2002 


\section{INTRODUCTION}

During 1995-2002, the valuation of euro-area corporations went through an unprecedented boom-bust cycle. Recently published flow-of-funds data on balance sheet positions of nonfinancial corporations in the euro area suggest that valuations of equity mushroomed from 70 percent of GDP in 1995 to some 155 percent of GDP in 2000 (Figure 1) ${ }^{2}$ By end2002 , equity valuations are estimated to have declined to around 90 percent of GDP, closely mirroring the valuation cycle in the United States. Moreover, judged against the long stretch of U.S. data since World War II, the recent boom-bust cycle in U.S. equity valuations seems to have been of an unprecedented magnitude (Figure 1). ${ }^{3}$ While comparable postwar data for the euro area are not available, it seems safe to infer from the U.S. time series record that the area's recent corporate valuation cycle has been similarly out-of-the-ordinary.

Figure 1. Valuations of Equity of Nonfinancial Corporations in Euro Area and United States (In percent of GDP)

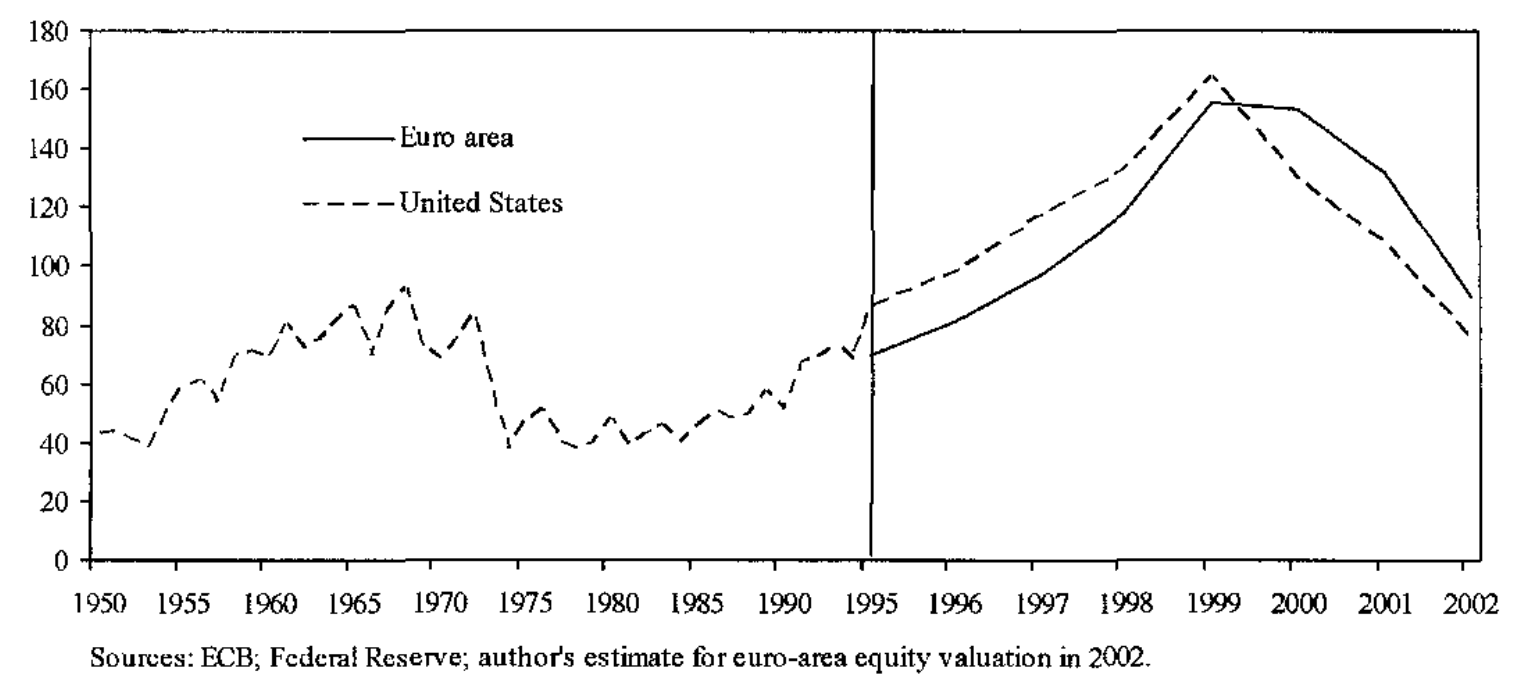

${ }^{2}$ The ECB's Report on Financial Structures (2002) provides sectoral balance sheet data for the euro area and most member countries.

${ }^{3}$ For the postwar period, Davis (2003) reports that the declines in U.S. nominal (and real) share price indices in the early 1970 s were comparable to the declines during the recent bear market episode. However, as illustrated by Figure 1, this comparison does not take into account that the more recent bear market in equities was preceded by an unprecedented boom; furthermore equity valuations as a share of GDP have increased markedly since the early 1970s. As regards comparisons with prewar data, U.S. share price indices suggest, however, that the amplitude of the 1925-32 boom-bust cycle is unlikely to be matched by the more recent bubble episode. 
The recent boom-bust cycle in the area's equity valuations has left behind a legacy of high corporate indebtedness. During the second half of the 1990 s, corporations faced soaring stock markets that seemed to signal a new and unprecedented era of growth and profit opportunities. In response, corporations embarked on an investment binge to expand their assets-in-place. To finance the investment boom, corporations relied increasingly on borrowing as their financing needs quickly outpaced the availability of internal funds and net equity issues. At the peak of the corporate boom in 2000, indebtedness, mainly in the form of bank loans, had risen to over 70 percent of GDP, up from 58 percent of GDP in 1995. Nevertheless, the higher debt levels seemed inconsequential during the boom years given equity valuations that had risen to some 155 percent of GDP. As stock market valuations crashed in 2001 and 2002, however, an unexpected legacy of high leverage was left on corporations' balance sheets.

This paper discusses whether the recent sharp rise in the area's corporate indebtedness could have adverse effects on euro-area investment. Theory holds no clear answers on this question. One theoretical benchmark, based on perfect capital markets, suggests that corporate leverage should not affect investment. Or, as it is sometimes put, corporate investment decisions should not depend on how the liability side of the balance sheet is sliced up into debt and equity. ${ }^{4}$ On the other hand, several recent models of corporate investment behavior that assume imperfect capital markets predict that the financial position of corporate borrowers will impinge on investment decisions. These models argue that more leveraged corporations will find it more difficult or more costly to obtain financing than corporations with identical investment projects but sounder financial positions. ${ }^{5}$

Several parties have voiced concerns about overleveraged balance sheets of euro-area corporations. Financial market analysts have linked the area's persistent investment slump to excessive leverage levels. ${ }^{6}$ Official forecasters have also expressed concern, with the European Commission noting in its Autumn 2002 forecasts that the area's corporations may have become "...more concerned with cleaning up their balance sheets than with planning new investments." But perhaps the most striking evidence of heightened concern regarding leverage of euro-area corporations comes from international investor surveys. For example, Merril Lynch's monthly Fund Manager Survey asks global financial investors: What would

\footnotetext{
${ }^{4}$ See Miller (1991) for a strongly argued statement of this position.

${ }^{5}$ Hubbard (1998) and Hall and Wetherhilt (2002) review the various strands of the "leverage matters" literature.

${ }^{6}$ See, for example, J.P. Morgan's Economic \& Policy Research notes (September 13, 2002; and February 21, 2003). Credit Suisse First Boston's Euro Area Weekly (June 14, 2001) seems to have been one of the earliest pieces arguing that investment prospects in the euro area could be severely constrained by corporations' financial positions.
} 
you most like to see companies do with their cash flow at the current time? For euro-area corporations, preferred actions in recent surveys were distributed as follows: ${ }^{7}$

\begin{tabular}{lcc} 
Preferred action (in percent) & June 2002 Survey & March 2003 Survey \\
\cline { 2 - 3 } Increase repayment of debt & 54 & 62 \\
Repurchase equity & 19 & 9 \\
Maintain/increase capital spending & 18 & 12 \\
Increase dividend payments & 4 & 14 \\
Don't know & 4 & 3
\end{tabular}

Thus, according to the March 2003 survey, a clear majority of investors (62 percent) preferred reducing leverage; only a minority (12 percent) preferred maintaining or increasing capital spending. And, compared with the June 2002 survey, investors have become more concerned about the area's corporate leverage. Moreover, comparison of survey results across the major currency areas suggests that investors' preferences for deleveraging are most pronounced for euro-area corporations. In the March 2003 survey, the percentages preferring repayment of debt by U.S. and Japanese corporates were 51 and 45 percent.

The paper concludes that the possible fallout from the area's corporate boom-bust cycle for future investment merits close attention by forecasters and policymakers, not least because the magnitude of the area's equity boom-bust cycle was unprecedented-at least from a postwar perspective--and cannot be traced to a "mere high-tech bubble." The unprecedented size of the valuation cycle also suggests that behavioral relationships linking investment and leverage based on historical data should be viewed with caution. Nevertheless, macroeconomic time-series evidence, consistent with firm panel-data evidence reported by other papers, ${ }^{8}$ suggests that excessive leverage can have substantial negative effects on corporate investment. The paper's focus on corporate investment is, however, somewhat limiting because investment cuts are not the only way to reduce leverage, with other deleveraging options including cost cutting, reducing dividends, and issuing new equity. ${ }^{9}$

The remainder of the paper is organized as follows. Section II sketches the paper's underlying model of corporate investment. Section III reviews balance sheet and flows-offunds data for the area's nonfinancial corporate sector, contrasting them with corporate trends in the United States and also comparing Germany's corporate trends with those in the euro area excluding Germany. Section IV discusses regression evidence that tries to shed light on whether leverage indicators affect corporate investment in aggregate time series. Section V concludes.

${ }^{7}$ The June 2002 survey was the first to include this question.

${ }^{8}$ See Vermeulen (2002) and IMF (2003, Chapter II).

${ }^{9}$ Benito and Young (2002) provide a classification of corporate balance sheet repair options. 


\section{INVESTMENT AND FinANCIAL STRUCTURE}

In a bare-bones model of corporate investment, capital markets are perfect and changes in a firm's desired capital stock reflect only changes in expected profitability or changes in the user cost of capital-the firm's financial structure plays no role in determining investment. The two forces driving changes in a firm's desired capital stock in the bare-bones model are illustrated in Figure 1. ${ }^{10}$ The demand for capital (D) slopes down because an increase in the cost of capital reduces firms' desired capital stock; the location of the D curve is determined by firms' growth and investment opportunities, i.e. the expected profitability of capital. The supply of funds for investing in capital (S) is drawn as a horizontal line at the level of the risk-adjusted market real rate of interest (a simplification that abstracts from other factors influencing the user cost of capital including depreciation and taxes). The desired capital stock is given by the intersection of the $\mathrm{S}$ and $\mathrm{D}$ curves at $\mathrm{K}^{*}$. The firm's leverage-as measured, for example, by the ratio of the firm's debt to assets-has no effect on a firm's value or investment decisions (Modigliani-Miller's (1958) proposition I).

Figure 2. Corporate Investment and Financial Structure

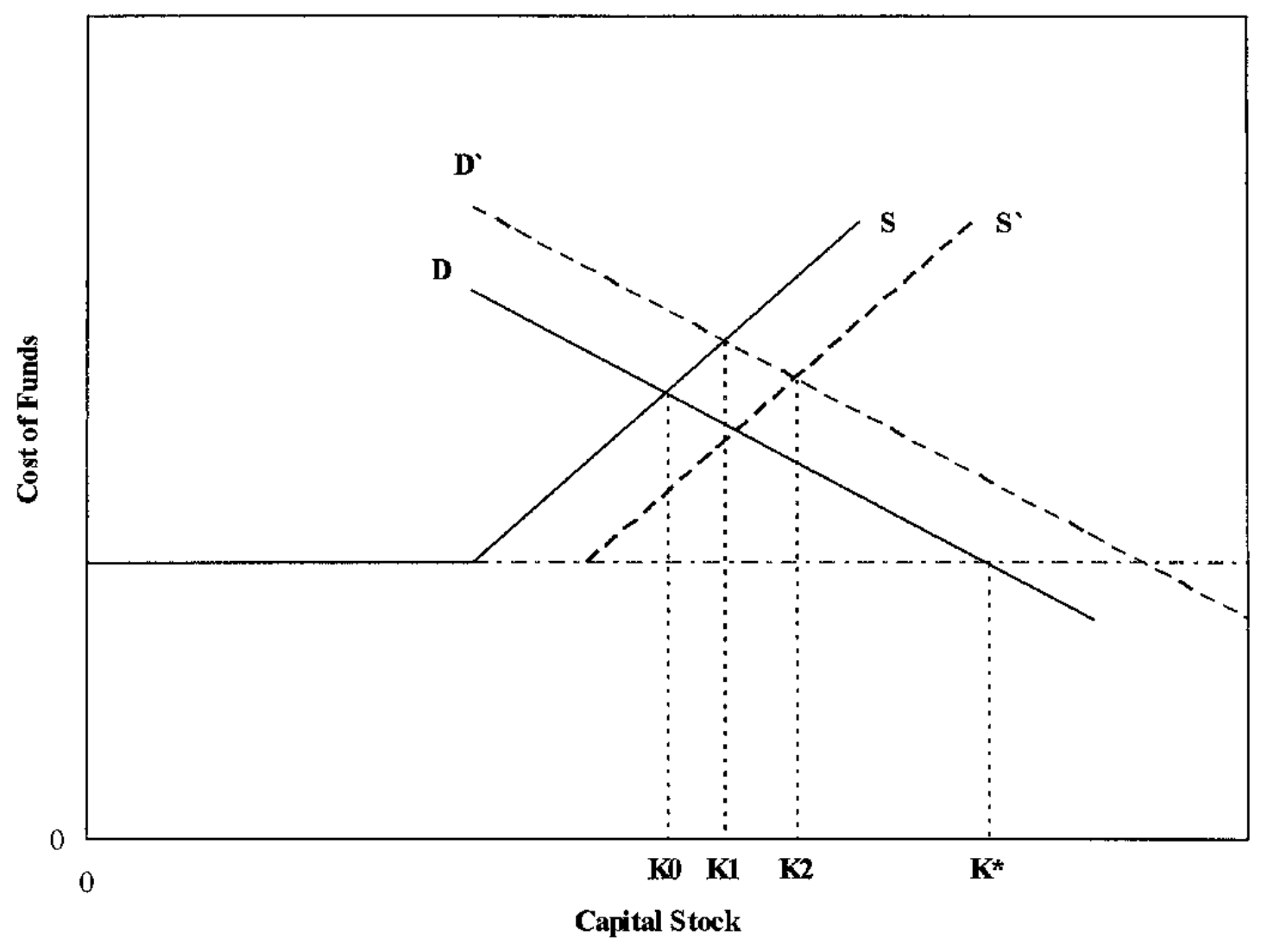

${ }^{10}$ See Hubbard (1998) 
With capital market imperfections, leverage matters for investment decisions. For example, owing to agency costs in the supply of finance in an asymmetric information setting (reflecting adverse selection, moral hazard, or costly state verification), investments that require a firm to draw on external borrowing are likely to be associated with higher cost of funds. This idea is captured in Figure 1 by assuming that the supply curve for funds begins sloping upward at some point (matching the point where the desired capital stock exceeds the firm's net worth) as providers of external funds need to be compensated for the additional risk of uncollateralized lending. As a consequence, the desired capital stock $\left(\mathrm{K}_{\mathrm{o}}\right)$ in this setting is smaller than in the bare-bones model case $\left(\mathrm{K}^{*}\right)$ because the marginal cost of funds is higher.

In this more realistic capital market setting, the so-called financial accelerator mechanism aggravates cycles in corporate investment. An "investment boom" in Figure 1 corresponds to a shift to the right in the D curve to $\mathrm{D}$ ', resulting in a higher desired capital stock $\left(\mathrm{K}_{1}\right)$. At the same time, however, boom periods will also tend to positively affect firms' net worth and collateral, shifting the upward-sloping part of the $S$ curve to the right to $S$ ', reducing the cost of funds and raising the desired capital stock further $\left(\mathbf{K}_{2}\right)$. The latter effect is the "financial accelerator mechanism" that magnifies the impact of shocks on investment by affecting the firm's financing choices. An "investment bust" corresponds to a similar stylized sequence of events in reverse, with the financial accelerator crimping investment through declines in firms' net worth and collateral.

In a still more realistic setting, firms can also invest in financial assets. As will be highlighted by the analysis of the balance sheet and flow of funds data below, nonfinancial corporations in the euro area responded to the equity valuation boom in the second half of the 1990s by significantly stepping up net acquisitions of financial assets. Thus, focusing only on corporate capital spending would miss a significant chunk of the corporate investment boom during the second half of the $1990 \mathrm{~s}$. To the extent that financial acquisitions were financed through debt or not hedged against foreign exchange risk, changes in financial asset prices or exchange rates could reinforce the financial accelerator mechanism.

Simulation models suggest that the size of financial accelerator effects can be very sensitive to steady-state assumptions regarding leverage and bank lending policies. For example, Hall and Wetherilt (2002) report numerical simulations illustrating how financial accelerator effects amplify the effects of monetary and productivity shocks on output, investment, and asset prices. The simulations highlight that the output and investment effects of shocks are much larger if corporations are assumed (in steady state) to be more highly leveraged or banks' lending policies are more restrictive because of high loan-monitoring cost.

In the case of the euro area, available empirical evidence indicates that the health of corporate balance sheets has an impact on investment, particularly during downturns and in the case of small firms. In a study of firm-level data for Germany, France, Italy, and Spain, Vermeulen (2002) finds that balance sheet indicators of leverage, liquidity, and creditworthiness have a significant effect on firms' investment activity, with effects more pronounced during downturns than in upturns and stronger for smaller than for medium- and 
large-sized firms; IMF (2003, Chapter II) reports similar leverage effects on investment using a different set of euro-area firm level data.

\section{The EuRo-AREA's CoRPorate BoOM-BuST CYCle: STYLIZEd FACTS}

As background, it is useful to take note of the flow-of-funds identity linking corporate funds' uses and sources. The change in corporate debt $(\Delta \mathrm{D})$ can be written as:

$$
\Delta \mathrm{D}=(\mathrm{I}+\Delta \mathrm{FA}-\mathrm{IF})-\Delta \mathrm{E}=\mathrm{CORPGAP}-\Delta \mathrm{E},
$$

where I denotes capital investment, $\triangle F A$ stands for net financial acquisitions, IF for internal funds, and $\Delta \mathrm{E}$ is net issuance of equity. The corporate financing gap (CORPGAP) equals investment (capital and financial) minus internal funds and has to be financed by debt or equity. The balance sheet of corporations can be written as:

$$
\mathrm{V}=\mathrm{K}+\mathrm{FA}=\mathrm{D}+\mathrm{E}
$$

i.e., firms' market value (V) equals on the asset side the market valuations of capital (K) and financial assets (FA), while the liability side is the sum of debt and equity valued at market prices. The stock variables in equation (2) will deviate from the cumulated changes of their counterparts in equation (1) owing to depreciation (in the case of the capital stock) and valuation gains or losses (in the case of financial assets and liabilities).

Turning to the stylized facts, the boom-bust cycle in the euro area's equity valuations seemed to have had little grounding in conventional fundamentals underpinning stock prices (Figure 3, Table 1). During the boom phase, both equity valuations as a percent of GDP and an estimate of Tobin's q more than doubled. ${ }^{11}$ Since 2000, the valuation indicators have more or less plummeted back to close to 1995 levels. In a basic equity valuation model, stock prices would react positively to higher expected profitability (dividend) growth and negatively to higher interest rates. While the area's real interest rate has declined since 1995, the expected real growth rate of corporate profits seems to have fallen by even more. ${ }^{12}$ This admittedly rather casual analysis would leave a large equity risk premium decline (during the

\footnotetext{
${ }^{11}$ Equity valuations for the euro area include quoted and nonquoted shares. The calculation of Tobin's $q$ is described in Table 1 .

12 The real interest rate is a ten-year rate and taken from the (November) Consensus Forecasts; real growth of expected profitability was calculated as the expected three-year average of nominal growth of expected profitability minus the expected (ten-year) inflation rate, again taken from (November) Consensus Forecasts. Euro-area averages are calculated as the weighted average of Germany, France, Italy, and Spain.
} 
Figure 3. Euro Area: Investment and Financing of Non-Financial Corporations, 1995-2002

Value of Equities

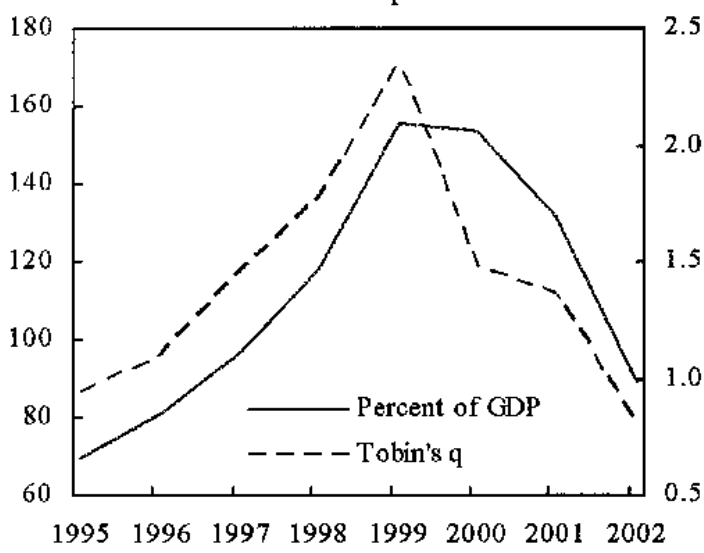

Equity Valuations: New vs. Old Economy $2 /$

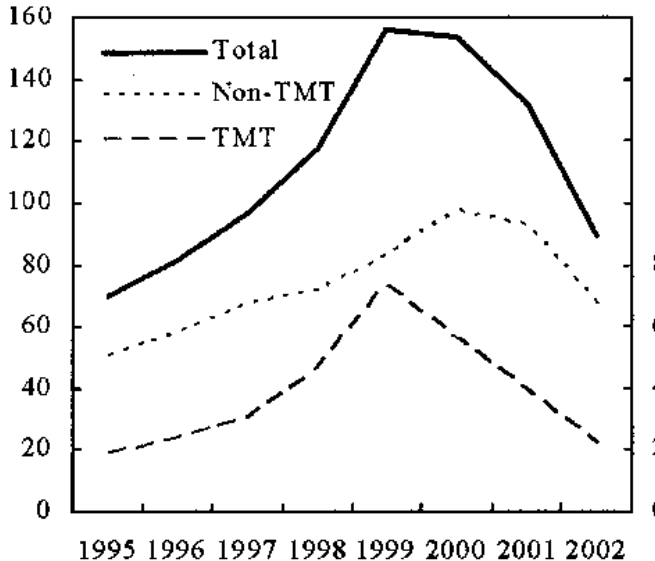

Financing 2

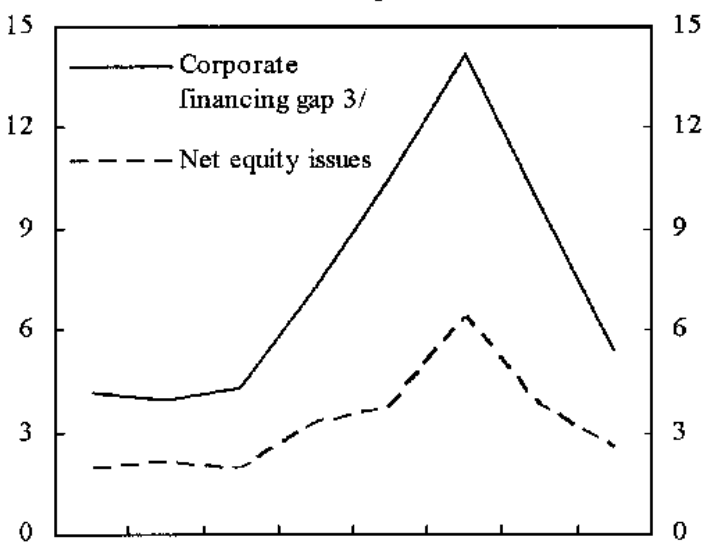

19951996199719981999200020012002
Equity Valuations: Determinants $1 /$

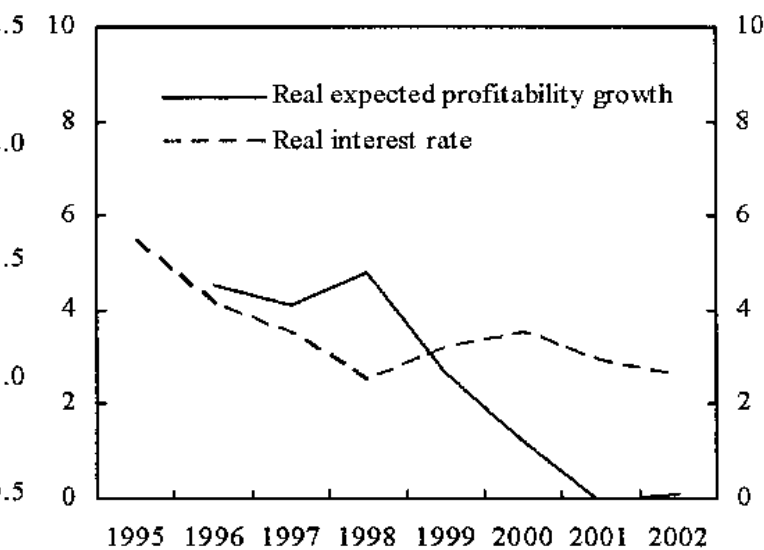

Investment $2 /$

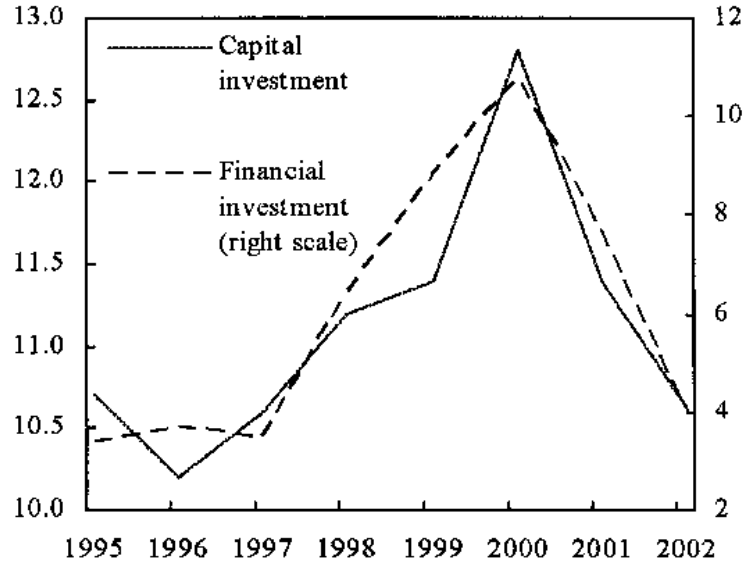

Leverage

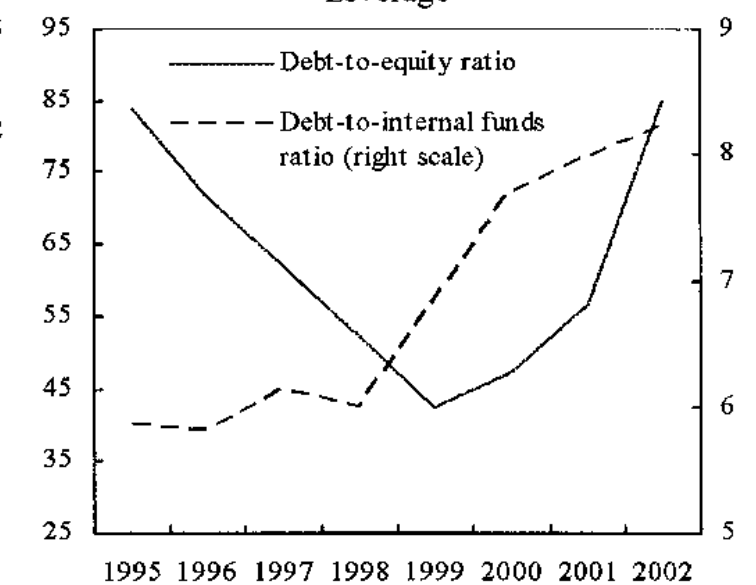

Sources: ECB; Consensus Forecasts; data for 2002 are projections.

1/ Based on Consensus Forecasts (weighted average of Germany, France, Italy, and Spain). 2/ Percent of GDP.

3/ Spending on capital and financial assets not covered by internal funds, as a percent of GDP. 
Table 1. Euro Area: Investment and Financing of Nonfinancial Corporations, 1995-2002 1/

\begin{tabular}{|c|c|c|c|c|c|c|c|c|}
\hline & 1995 & 1996 & 1997 & 1998 & 1999 & 2000 & 2001 & $\begin{array}{l}2002 \\
\text { Proj. }\end{array}$ \\
\hline & \multicolumn{7}{|c|}{ (Pcrcent of GDP, except when indicated otherwise) } & \\
\hline \multicolumn{9}{|l|}{ Flows } \\
\hline Investments & 14.1 & 13.9 & 14.1 & 17.6 & 20.2 & 23.6 & 19.0 & 14.6 \\
\hline Capital expenditure & 10.7 & 10.2 & 10.6 & 11.2 & 11.4 & 12.8 & 11.4 & 10.6 \\
\hline Net acquisition of financial assets & 3.4 & 3.7 & 3.5 & 6.4 & 8.8 & 10.8 & 7.6 & 4.0 \\
\hline Financing & 12.8 & 14.9 & 14.8 & 18.2 & 21.0 & 25.2 & 19.8 & 14.6 \\
\hline Internal funds & 9.9 & 10.0 & 9.8 & 10.3 & 9.7 & 9.4 & 9.3 & 9.2 \\
\hline Net incurrence of liabilities & 2.9 & 4.9 & 5.0 & 7.9 & 11.3 & 15.8 & 10.5 & 5.4 \\
\hline Debt financing & 0.9 & 2.8 & 3.1 & 4.6 & 7.6 & 9.4 & 6.7 & 2.9 \\
\hline Of which: Bank loans & 2.3 & 2.6 & 2.7 & 4.1 & 6.6 & 8.4 & 5.2 & $\ldots$ \\
\hline Equity financing & 2.0 & 2.1 & 1.9 & 3.3 & 3.7 & 6.4 & 3.8 & 2.5 \\
\hline Statistical discrepancy $2 /$ & -1.3 & 1.0 & 0.7 & 0.6 & 0.8 & 1.6 & 0.8 & 0.0 \\
\hline \multicolumn{9}{|l|}{ Stocks } \\
\hline Total value of nonfinanical corporations & 1.27 .6 & 139.4 & 157.2 & 179.7 & 222.0 & 225.8 & 205.8 & 165.1 \\
\hline Debt & 58.1 & 58.1 & 60.2 & 61.7 & 66.3 & 72.3 & 74.4 & 75.8 \\
\hline Of which: Bank loans & 52.5 & 52.5 & 54.7 & 55.9 & 59.9 & 65.5 & 66.3 & 69.6 \\
\hline Equity (at market value) & 69.4 & 81.3 & 97.0 & 118.0 & 155.7 & 153.5 & 131.4 & 89.3 \\
\hline Nonfinancial assets & 44.0 & 49.9 & 56.8 & 68.4 & 87.3 & 81.2 & 65.0 & $\ldots$ \\
\hline Financial assets & 83.6 & 89.5 & 100.4 & 111.3 & 134.8 & 144.6 & 140.8 & $\ldots$ \\
\hline \multicolumn{9}{|l|}{ Memorandum items } \\
\hline Tobin's q 3/ & 1.0 & 1.1 & 1.3 & 1.4 & 1.8 & 1.7 & 1.4 & 0.9 \\
\hline Corporate financing gap $4 /$ & 4.2 & 3.9 & 4.3 & 7.3 & 10.5 & 14.2 & 9.7 & 5.4 \\
\hline Debt-to-equity (percent) & 83.7 & 71.5 & 62.1 & 52.3 & 42.6 & 47.1 & 56.6 & 84.9 \\
\hline Debt-to-assets (percent) & 45.6 & 41.7 & 38.3 & 34.3 & 29.9 & 32.0 & 36.1 & 45.9 \\
\hline Debt-to-internal funds (ratio) & 5.8 & 5.8 & 6.1 & 6.0 & 6.8 & 7.7 & 8.0 & 8.2 \\
\hline
\end{tabular}

Sources: ECB; Eurostat; and author's calculations and projections.

1/ Data on internal funds in 1995 are adjusted to eliminate Germany's transfer of the Treuhand agency's debt to the Redemption Fund for Inherited Liabilitics; data for 2000 include UMTS payments.

2/ Difference between financial balances derived from the capital account and from the financial account; plus(minus) sign means that financial account balance is smaller(larger) than capital account balance.

3 / Tobin's $q$ is defined as the ratio between the market value and the replacement value of non-financial assets. It is approximated by the ratio of the market valuation of capital based on equation (2) and an estimate of the replacement value of the capital stock that sets Tobin's q in 1995 at one and calculates the capital stocks afterwards using a depreciation rate of 10 percent.

4/Corporate financing gap is defined as investments (capital and financial) minus intcrnal funds. 
boom phase) followed by an equally sharp risk premium reversal (during the bust phase) as the "residual explanation" for the observed equity boom-bust cycle. ${ }^{13}$

The buildup and bursting of the high-tech bubble seems to explain only part of the swing in the area's equity valuations. While the amplitude of the price swing in technology-mediatelecommunication (TMT) shares was much larger than in "old economy shares," this does not imply that the TMT sectors were solely responsible for the cycle in the area's overall equity valuations. Rough approximations of the relative contributions of TMT and non-TMT sectors to the area's equity valuations (as a percent of GDP) suggest that the TMT sectors played indeed a key role in driving the overall valuation cycle, but non-TMT sectors also contributed importantly to the boom-bust cycle (Figure 3, middle left-hand panel). ${ }^{14}$

Corporations' capital and financial investment spending during 1995-2002 mirrored closely the boom-bust cycle in equity valuations (Figure 3, middle-right panel, Table 1). Euro-area corporate spending on capital goods picked up and peaked at 123/4 percent of GDP in 2000 (data for 2000 include spending on UMTS licenses of about 1 percent of GDP). Spending by corporations on financial assets, mainly in the form of net acquisition of shares, rose even more sharply, peaking at 103/4 percent of GDP in 2000 (up from 33/4 percent of GDP in 1996), but has since moderated significantly.

From the financing side, the boom in capital and financial investment spending was initially helped by a low corporate financing gap, but as the boom matured debt financing took increasingly center stage (Figure 3, lower-right panel, Table 1). In 1995, debt financing accounted only for about 1 percent of GDP of the overall investment (capital and financial) requirement of some 14 percent of GDP. As the investment boom gathered pace, however, debt financing became the dominant source for funding the corporate financing gap.

The corporate boom-bust cycle has left the area's corporate leverage at high levels (Figure 3, lower right-hand panel, Table 1). Leverage is proxied by two measures: the ratio of debt to the market value of firms $(\mathrm{D} / \mathrm{V})$ and the ratio of debt to internal funds $(\mathrm{D} / \mathrm{IF})$; the first of these two measures is dominated by market valuations of equity in the denominator of the ratio, making it difficult to interpret the measure when equity markets undergo boom-bust

${ }^{13}$ See IMF (2000, Chapter III) for a discussion of equity risk premia and stock market valuations during the 1990s. The puzzle of what drove the area's equity valuations during the second half of the 1990s is deepened by the stylized fact that the area's trend labor productivity growth rate decelerated during that time.

${ }^{14}$ The TMT sectors share of overall equity valuations (as a percent of GDP) was constructed using their (year-end) market capitalization share in Eurostoxx market capitalization (excluding financial corporations). While this construction method is likely to be accurate for quoted shares, it represents only a rough guess for nonquoted TMT shares and is in fact likely to overstate the contribution to overall equity valuations by TMT sectors. 
cycles. ${ }^{15}$ Nevertheless, both leverage measures suggest that once the boom reversed, leverage rose sharply relative to the peak of the boom in 2000 .

A comparison of the recent corporate cycles in the euro area and the United States suggests that both cycles were largely driven by common shocks, but the U.S. corporate sector appears to have adjusted faster to the bursting of the bubble (Figure 4). Changes in Tobin's q and capital and financial investment spending were closely aligned in both major currency areas, particularly during the boom part of the cycle. At the same time, the pullback in investment spending (both capital and financial) was more pronounced in the United States during the downswing, reflected in a corporate financing gap that was reduced much faster than in the euro area. As a consequence, debt accumulation and the increase in leverage (based on the debt-to-internal funds ratio) in the U.S. corporate sector during 1996-2000 was more restrained than in the euro area, notwithstanding the fact that U.S. net equity financing of corporations was negative throughout the cycle.

Inside the euro area, there are some indications that present corporate balance sheet pressures in Germany are more pronounced than in the rest of the area (Figure 5, Table 2). As in the previous comparison between the euro area and the United States, the common features of the investment and financing cycles in Germany and the euro area excluding Germany are striking. But there are also two noteworthy differences. First, leverage of Germany's nonfinancial corporations since 1995 appears to have risen more sharply then in the rest of the area. And second, the boom in the valuation of outstanding equity in Germany during 1995-1999 was more subdued than in the rest of the euro area, as indicated by Tobin's q. The more subdued boom may in part have reflected market perceptions of lower growth and investment opportunities in Germany. Consistent with the perception that growth and investment opportunities of German companies may have lagged behind the rest of the euro area, the availability of internal funds for corporate investment in Germany dwindled significantly during 1996-2000. Germany's national income accounts data for nonfinancial corporations suggest, however, that the drying up of internal funds has been less a consequence of falling profits but reflected a marked trend to higher dividend distributions since 1995 (Table 2, memorandum items). This apparent trend toward higher dividend distributions could be indicative of a perceived lack of investment and growth opportunities within Germany's corporate sector or the impact of changing tax incentives.

${ }^{15}$ See Taggart (1985) for a review of different measures of leverage; Rajan and Zingales (1995) discuss the international comparability of leverage measures. 
Figure 4. Euro Area and United States: Investment and Financing of Nonfinancial Corporations, 1995-2002
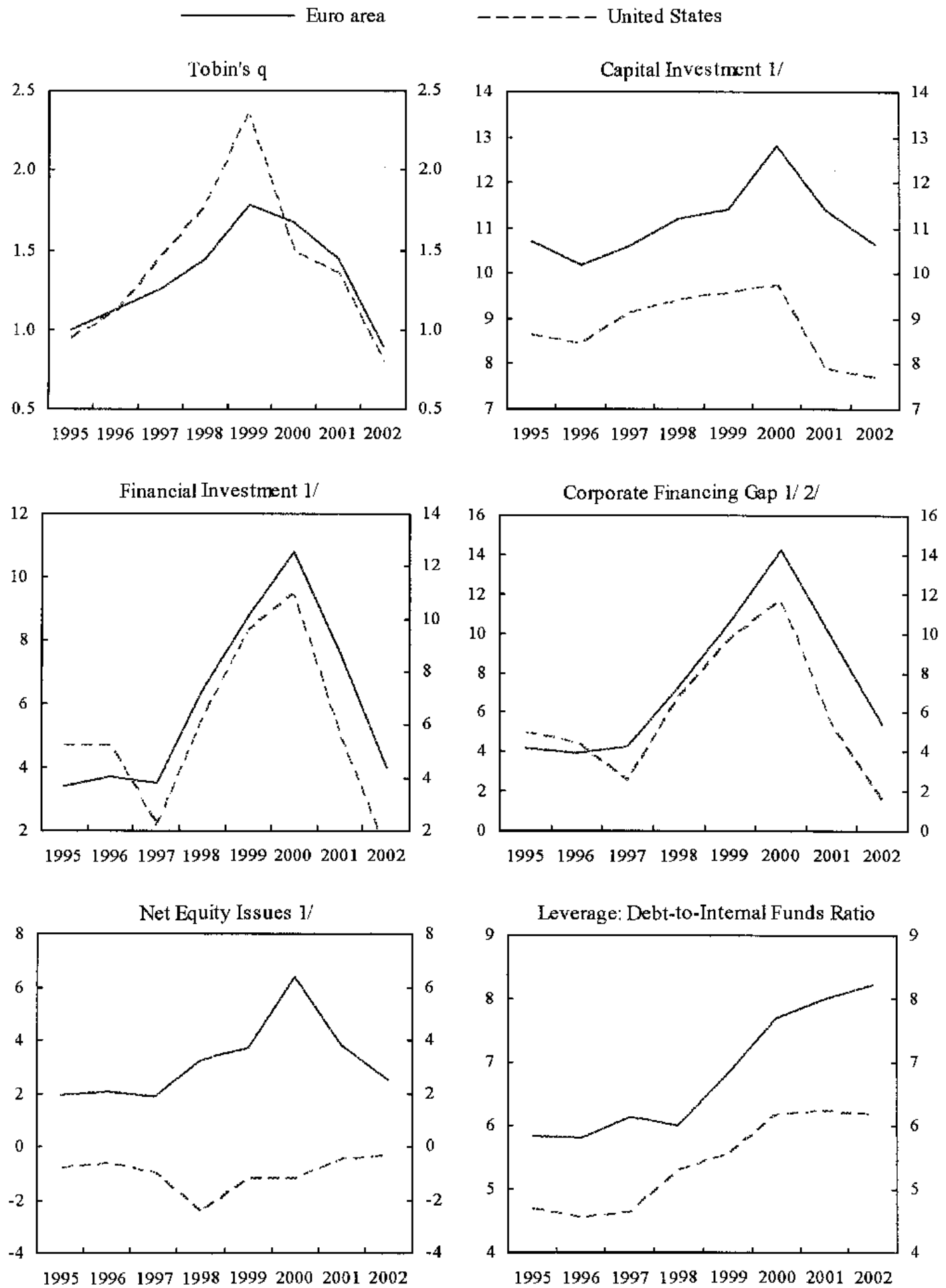

Sources: ECB; Federal Reserve; Consensus Forccasts; euro-area data for 2002 are projections.

1/ Percent of GDP.

$2 /$ Spending on capital and financial assets not covered by internal funds, as a percent of GDP. 
Figure 5. Germany and Euro Area Excluding Germany: Investment and Financing of Nonfinancial Corporations, 1995-2002
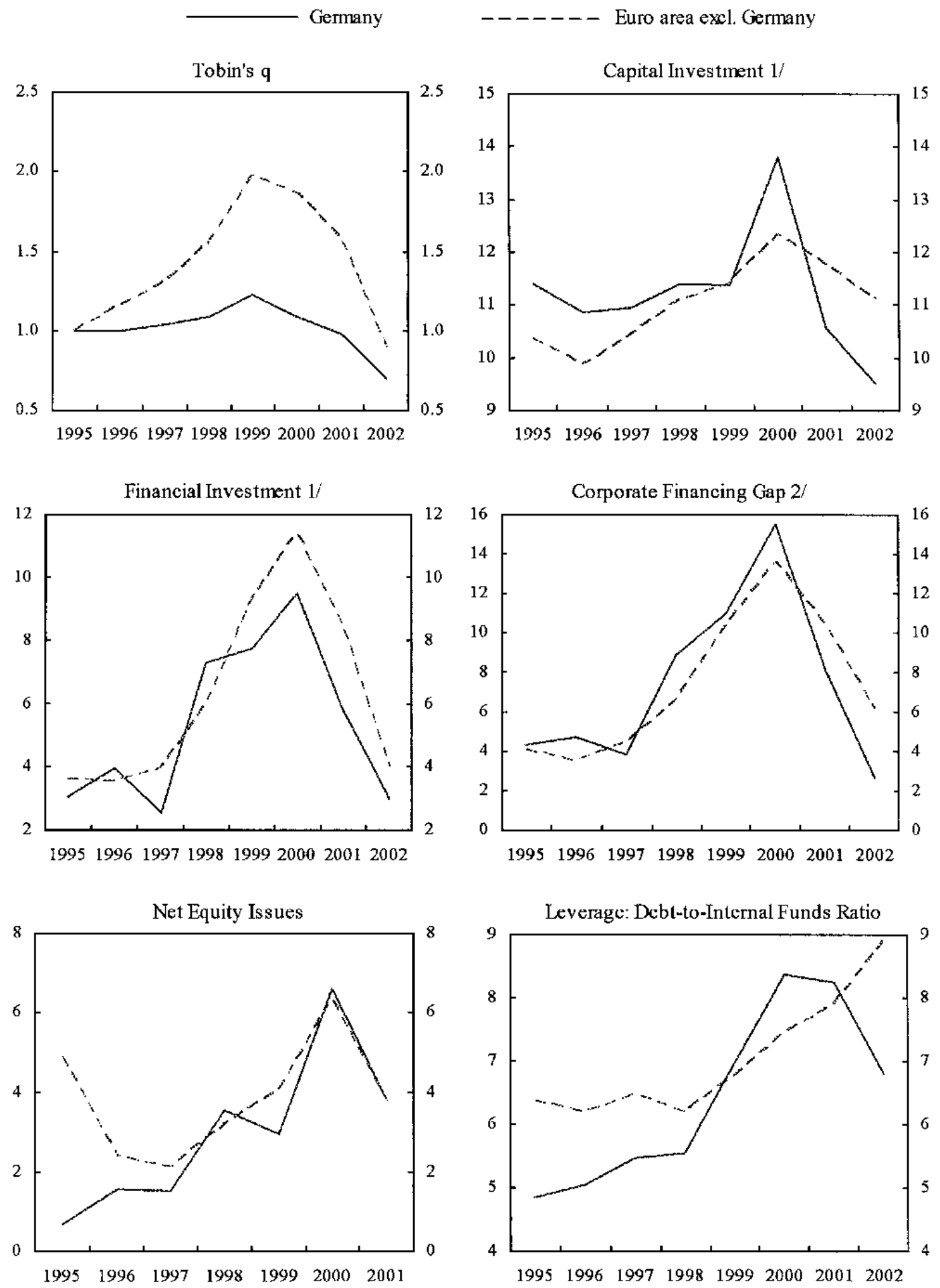

Sources: ECB; Bundesbank; data for 2002 are projections.

1/ Percent of GDP.

2/ Spending on capital and financial as sets not covered by intemal funds, as a percent of GDP. 
Table 2. Germany: Investment and Financing of Nonfinancial Corporations, 1995-2002 1/

\begin{tabular}{|c|c|c|c|c|c|c|c|c|}
\hline & 1995 & 1996 & 1997 & 1998 & 1999 & 2000 & 2001 & $\begin{array}{l}2002 \\
\text { Proj. }\end{array}$ \\
\hline & \multicolumn{7}{|c|}{ (Percent of GDP, except when indicated otherwise) } & \\
\hline \multicolumn{9}{|l|}{ Flows } \\
\hline Investments & 14.4 & 14.8 & 13.5 & 18.7 & 19.1 & 23.3 & 16.4 & 12.5 \\
\hline Capital expenditure & 11.4 & 10.9 & 10.9 & 11.4 & 11.4 & 13.8 & 10.6 & 9.5 \\
\hline Net acquisition of financial assets & 3.0 & 4.0 & 2.6 & 7.3 & 7.7 & 9.5 & 5.8 & 3.0 \\
\hline Financing & 15.1 & 15.0 & 13.9 & 18.4 & 18.2 & 25.0 & 15.9 & $\ldots$ \\
\hline Internal funds & 10.1 & 10.1 & 9.6 & 9.8 & 8.2 & 7.8 & 8.2 & 9.8 \\
\hline Net incurrence of Liabilities & 5.0 & 4.9 & 4.2 & 8.6 & 10.0 & 17.2 & 7.6 & $\ldots$ \\
\hline Debt financing & 4.4 & 3.4 & 2.7 & 5.0 & 7.1 & 10.6 & 3.8 & ... \\
\hline Of which: Bank loans & 2.2 & 3.6 & 2.9 & 5.2 & 7.0 & 10.2 & 3.4 & $\ldots$ \\
\hline Equity francing & 0.7 & 1.6 & 1.5 & 3.5 & 2.9 & 6.6 & 3.8 & $\ldots$ \\
\hline Statistical discrepancy $2 /$ & 0.7 & 0.2 & 0.4 & -0.3 & -0.9 & 1.7 & -0.5 & ... \\
\hline \multicolumn{9}{|l|}{ Stacks } \\
\hline Total value of norfinanical corporations & 93.6 & 103.2 & 113.9 & 125.5 & 147.8 & $\mathrm{f} 47.3$ & 142.5 & 121.8 \\
\hline Debt & 49.0 & 51.0 & 52.8 & 54.5 & 57.0 & 65.2 & 68.0 & 66.8 \\
\hline Of which: Bank loans & 45.9 & 48.1 & 50.2 & 52.1 & 54.8 & 62.6 & 64.9 & 63.2 \\
\hline Equity (at market value) & 44.6 & 52.2 & 61.2 & 71.1 & 90.7 & 82.2 & 74.5 & 55.0 \\
\hline Nonfinancial assets & 42.2 & 34.6 & 38.2 & 42.6 & 51.0 & 43.6 & 38.2 & $\ldots$ \\
\hline Financial assets & 51.4 & 68.6 & 75.8 & 82.9 & 96.8 & 103.8 & 104.4 & $\cdots$ \\
\hline \multicolumn{9}{|l|}{ Memorandum items } \\
\hline Tobin's q $3 /$ & 1,00 & 0.99 & 1.03 & 1.09 & 1.22 & 1.09 & 0.97 & 0.70 \\
\hline Corporate financing gap $4 /$ & 4.3 & 4.7 & 3.9 & 8.9 & 10.9 & 15.5 & 8.1 & 2.7 \\
\hline Debt-to-equity (percent) & 109.9 & 97.6 & 86.3 & 76.6 & 62.9 & 79.3 & 91.2 & 121.6 \\
\hline Debt-to-assets (percent) & 52.4 & 49.4 & 46.3 & 43.4 & 38.6 & 44.2 & 47.7 & 54.9 \\
\hline Debt-to-internal funds (ratio) & 4.9 & 5.0 & 5.5 & 5.5 & 7.0 & 8.4 & 8.2 & 6.8 \\
\hline Operating surplus & 10.0 & 9.9 & 10.6 & 11.7 & 11.4 & 11.2 & 11.5 & $\ldots$ \\
\hline Dividends & 7.4 & 6.9 & 8.2 & 9.7 & 10.1 & 10.9 & 12.0 & $\ldots$ \\
\hline
\end{tabular}

Sources: Bundesbank; Federal Statistical Office; and own calculations and prajcctions.

1/ Data on internal funds in 1995 are adjusted to eliminate the transfer of the Treuhand agency's debt to the Redemption Fund for Inherited Liabilities; data for 2000 include UMTS payments.

$2 /$ Difference between financial balances derived from the capital account and from the financial account; plus(minus) sign means that financial account balance is smaller(larger) than capital account balance.

3 / Tobin's $q$ is defined as the ratio between the market value and the replacement value of non-financial assets. It is approximated by the ratio of the market valuation of eapital based on equation (2) and an estimate of the replacement value of the capital stock that scts Tobin's $q$ in 1995 at one and calculates the capital stocks afterwards using a depreciation rate of 10 percent. 4/ Corporate financing gap is defined as invesiments (capital and financial) minus internal funds. 


\section{INVESTMENT AND BALANCE SHEET RESTRUCTURING}

This section provides regression evidence on the link between corporate investment and balance sheet restructuring. The term "balance sheet restructuring" is used here to mean that corporations adjust the variables on the right-hand side of (1) in an attempt to "normalize" the stock variables in equation (2), particularly the debt or leverage position. The corporate finance literature offers two competing paradigms of what corporations consider to be a "normal leverage positions": 16

- According to the trade-off paradigm, firms weigh the benefits and costs of debt, trading off the tax and incentive benefits of debt financing against the expected cost of financial distress. The trade-off paradigm predicts that corporates have welldefined targets for their desired debt-equity mix. If their actual financial structure deviates from targeted leverage, balance sheet restructuring aims at moving actual leverage back to target.

- According to the pecking-order paradigm, firms generally prefer internal to external finance, while among external financing options they prefer first to use safe debt, then risky debt, and finally, as a last resort, equity. A key implication of this alternative paradigm is that firms do not have a well-defined leverage target as in the case of the trade-off paradigm. Balance sheet restructuring would amount to restoring firms' preferred pecking order, for example by bringing a measure of the corporate financing gap back to what is viewed as a normal level. Under this paradigm, the observed debt-equity mix can be largely viewed as an accident of history.

There seems to be considerable evidence in favor of the pecking-order paradigm, particularly from direct surveys of how corporations decide on their financial structure. ${ }^{17}$ Nevertheless, it is plausible that while corporations allow leverage to drift away from targets in the short run (consistent with the pecking-order paradigm), large deviations will eventually trigger efforts to bring leverage back to target in the longer run (consistent with the trade-off paradigm). ${ }^{18}$ In particular, corporations are likely to become highly focused on restoring leverage targets when their financial status threatens to deteriorate below certain thresholds, for example if the threat is the loss of investment grade status.

Against this background, the following regression was used to provide empirical evidence on the role of leverage in determining corporate investment:

\footnotetext{
${ }^{16}$ See Meyers (1984).

${ }^{17}$ See, for example, Graham and Campbell (2002).

${ }^{18}$ Hovakimian and others $(2002)$ call this compromise paradigm the "dynamic trade-off model."
} 


$$
\mathrm{IK}_{\mathbf{t}}=\alpha+\beta \mathrm{IK}_{\mathrm{t}-1}+\gamma \mathrm{GROWTH}_{\mathrm{t}-1}+\lambda \mathrm{LEVER}_{\mathrm{t}-1}+\varepsilon_{\mathrm{t}},
$$

where $\mathrm{IK}_{t}$ is the ratio of investment in year $t$ to the capital stock at the end of year $t-1$, GROWTH $_{t}$ is real GDP growth, LEVER ${ }_{t}$ is a leverage indicator, and $\varepsilon_{t}$ is the regression's error term. The two leverage measures used in the regressions are the debt-equity ratio $((\mathrm{D} / \mathrm{V})$ and the debt-internal-funds ratio (D/IF). The limited availability of consistent flow-offunds data over longer time spans dictated that the regression had to be restricted to Germany (as a proxy for the euro area) and the United States, with the sample period covering annual data for 1971-2001. The raw data (relative to historical mean) for the investment-capital ratio and the two leverage measures are plotted in Figure 6.

Equation (3) was designed to closely match the firm panel-data regressions used by Vermeulen (2002) and IMF (2003). ${ }^{19}$ To test for asymmetric leverage effects, the regressions were also estimated allowing for different effects between high- and low-leverage regimes:

$$
\mathrm{IK}_{\mathrm{t}}=\alpha+\beta \mathrm{IK}_{\mathrm{t}-1}+\gamma \mathrm{GROWTH}_{\mathrm{t}-1}+\left(\lambda^{+} \mathrm{I}_{\mathrm{t}-1}^{+} \mathrm{LEVER}_{\mathrm{t}-1}+\lambda \mathrm{I}_{\mathrm{t}-1}^{-} \mathrm{LEVER}_{\mathrm{t}-1}\right)+\varepsilon_{\mathrm{t}}
$$

where the indicator function $\mathrm{I}_{\mathbf{t}}^{+}$takes a value of 1 during years of above-average leverage and 0 during years of below-average leverage, while the indicator function $\mathrm{I}_{\mathrm{t}}^{-}$takes a 1 during years of below-average leverage and 0 during years of above-average leverage; an F-test can be used to test the restriction that the coefficients in the two leverage-regimes are the same.

The estimation results are broadly in line with a significant role for the leverage indicators, particularly during periods of above-average leverage (Table 3). First, the leverage indicators are generally rightly signed-higher leverage puts downward pressure on corporate investment-and significant except in the case of the debt-equity ratio for Germany. From Figure 6, it appears that the debt-equity ratio in Germany (and to a lesser extent in the United States) has a distinct downward trend and is below average at the end of the sample period. ${ }^{20}$ Second, there is evidence for asymmetric leverage effects, although the relevant Ftests generally do not reject the null hypothesis that the leverage coefficients are statistically the same in above- and below-average regimes. Third, the estimated coefficients for the leverage indicators are significant in an economic sense. For example, in the case of Germany the estimated coefficient for the debt-internal-funds ratio in the high-leverage regime is -0.70 .

\footnotetext{
${ }^{19}$ Including current and lagged values of Tobin's q yielded wrong-signed coefficients, echoing the results reported by Blanchard, Rhee, and Summers (1993) for the United States.

${ }^{20}$ Extracting an underlying trend from the leverage measures by applying a Hodrick-Prescott filter did improve the fit of the regressions on the debt-equity ratios but also raised issues of spurious correlation between the detrended leverage measures and the investment-capital ratio.
} 
Figure 6. Germany and United States: Corporate Investment and Leverage, 1971-2002

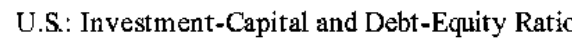

Germany: Investment-Capital and Debt-Equity Ratio
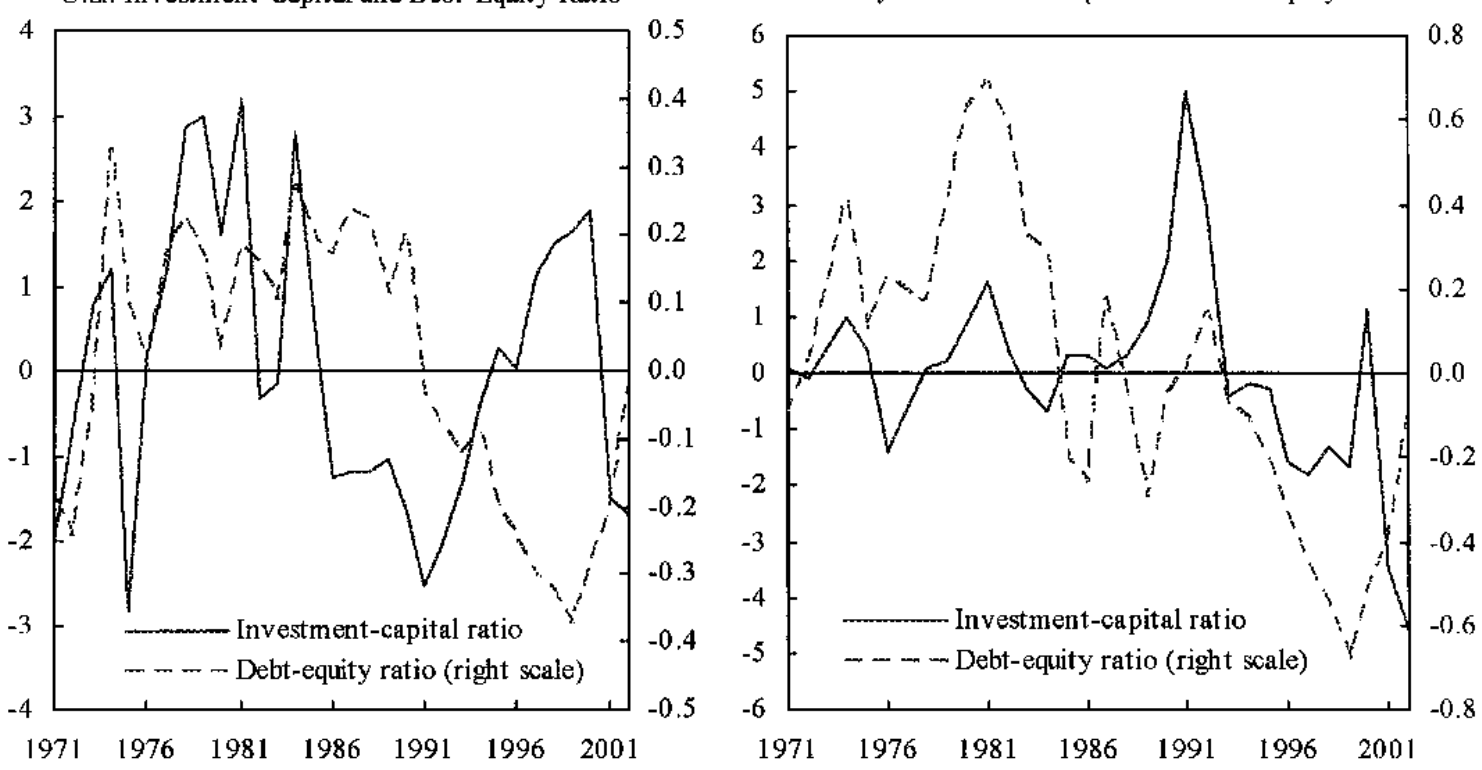

U.S.: Investment-Capital and Debt-Internal-Funds Ratio

Germany: Investment-Capital and Debt-Internal-Funds Ratio
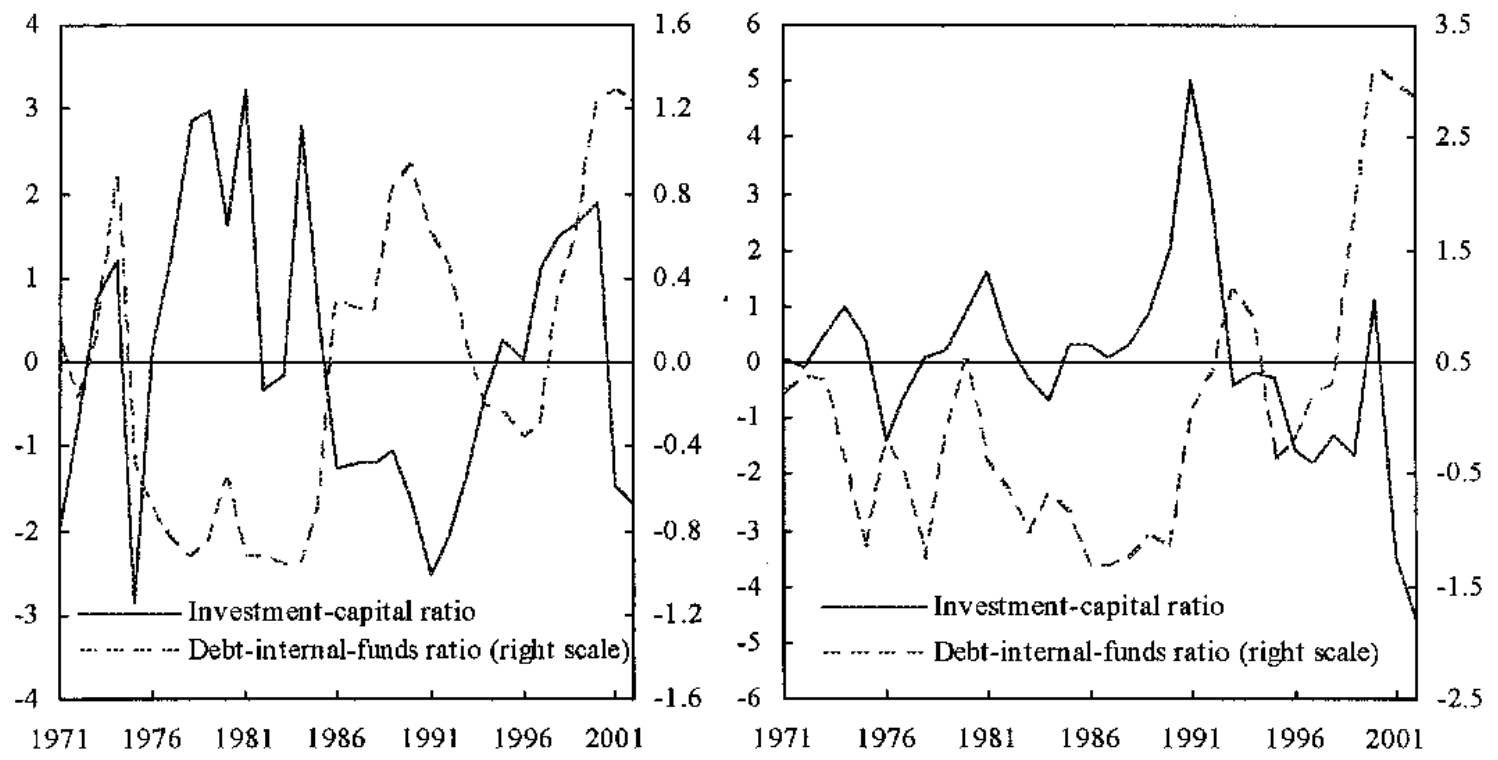

Sources: Federal Reserve; Bundesbank; and author's calculations. 
Table 3. Germany and United States: Corporate Investment and Leverage, 1971-2002

Estimated equation: $\mathrm{IK}_{\mathrm{t}}=\alpha+\beta \mathrm{IK}_{\mathrm{t}-1}+\gamma \mathrm{GROWTH}_{\mathrm{t}-\mathrm{I}}+\lambda \mathrm{LEVER}_{\mathrm{t}-1}+\varepsilon_{\mathrm{t}}$

\begin{tabular}{|c|c|c|c|c|c|c|c|c|}
\hline & \multicolumn{4}{|c|}{ Germany } & \multicolumn{4}{|c|}{ United States } \\
\hline & (1) & $(2)$ & (3) & (4) & (1) & $(2)$ & (3) & (4) \\
\hline \multirow[t]{2}{*}{ Constant } & 7.50 & 7.60 & 7.66 & 8.01 & 6.85 & 5.82 & 9.64 & 9.07 \\
\hline & $(2.71)$ & $(2.50)$ & $(3.21)$ & 3.21 & $(3.19)$ & $(2.99)$ & $(5.14)$ & 4.62 \\
\hline \multirow[t]{2}{*}{$\mathrm{IK}_{\mathrm{t}-1}$} & 0.47 & 0.47 & 0.47 & 0.46 & 0.46 & 0.62 & 0.24 & 0.33 \\
\hline & $(2.65)$ & $(2.52)$ & $(3.06)$ & $(2.94)$ & (2.81) & $(3.75)$ & (1.64) & $(1.92)$ \\
\hline \multirow[t]{2}{*}{ Growth $_{\mathrm{t}-1}$} & 0.38 & 0.37 & 0.32 & 0.32 & 0.18 & 0.18 & 0.15 & 0.11 \\
\hline & $(2.71)$ & $(2.49)$ & $(2.63)$ & $(2.53)$ & (1.38) & $(1.55)$ & $(1.41)$ & $(0.92)$ \\
\hline \multirow[t]{2}{*}{ (Debt-Equity) $)_{t-1}$} & 1.05 & & & & -1.42 & & & \\
\hline & (1.41) & & & & $(1.13)$ & & & \\
\hline \multirow[t]{2}{*}{ (Debt-Equity) $)_{t-1} I^{+}$} & & 0.93 & & & & -8.98 & & \\
\hline & & $(0.63)$ & & & & $(2.70)$ & & \\
\hline \multirow[t]{2}{*}{ (Debt-Equity) t-1 $^{-}$} & & 1.17 & & & & 4.77 & & \\
\hline & & $(0.72)$ & & & & $(1.70)$ & & \\
\hline \multirow[t]{2}{*}{ (Debt-Internal-Funds) $)_{t-1}$} & & & -0.56 & & & & -1.26 & \\
\hline & & & $(2.82)$ & & & & $(3.69)$ & \\
\hline \multirow[t]{2}{*}{ (Debt-Internal-Funds) $)_{\mathrm{t}-1} \Gamma^{+}$} & & & & -0.70 & & & & -1.93 \\
\hline & & & & $(2.21)$ & & & & $(2.56)$ \\
\hline \multirow[t]{2}{*}{ (Debt-Internal-Funds) $)_{t-1} \mathrm{I}^{-}$} & & & & -0.30 & & & & -0.47 \\
\hline & & & & $(0.62)$ & & & & $(0.54)$ \\
\hline$F(1,27) 3 /$ & & 0.01 & & 0.33 & & 5.88 & & 0.99 \\
\hline P-value & & 0.93 & & 0.57 & & 0.02 & & 0.33 \\
\hline DW & 2.04 & 2.04 & 2.37 & 2.37 & 1.88 & 2.05 & 1.95 & 1.93 \\
\hline $\mathrm{R}^{2}$ & 0.44 & 0.42 & 0.54 & 0.53 & 0.30 & 0.41 & 0.51 & 0.51 \\
\hline
\end{tabular}

Sources: WEO database; Federal Statistical Office; Bundesbank; Federal Reserve Bank; and author's estimates.

1/ Capital stock data for Germany were constructed by fixing the investment-capital ratio at 0.16 in 1971 and then cumulating investment by nonfinancial corporations assuming an annual depreciation rate of 10 percent. For the United States, the capital stock series corresponds to total tangible assets at historical cost.

2/ Figures in parentheses are t-statistics.

3/ F-test of restriction that leverage cocfficients are the same for high- and low-leverage regimes. 
With the debt-internal-funds ratio in 2001 exceeding its historical average by 3.0 , this translates into an adverse short-term effect on the investment-capital ratio in 2002 of about 2 percentage points, roughly equivalent to an investment-crimping effect of $13 / 4$ percent of GDP in 2002. Moreover, taking account of the lagged adjustment of the investment-capital ratio, the long-run effect of an increase in the debt-internal-funds ratio by 1.0 is a reduction in the investment-capital ratio by about 1.5 percentage points. And fourth, a comparison of the results for Germany and the United States suggests that the adverse effects of excess leverage are larger in the U.S. case. Extrapolating the results for Germany to the euro area, this finding is broadly consistent with the faster corporate adjustment process recently observed in the United States (Figure 4) and may reflect the more market-based financial intermediation system in the U.S.

\section{Conclusions}

The main implication of this paper is that the fallout from the area's corporate boom-bust cycle merits close attention by forecasters and policymakers. The euro area's recent equity boom-bust cycle seems to be an unprecedented event in postwar data, had little support from fundamental factors, and has left corporations highly leveraged. Moreover, the boom-bust cycle can not easily be dismissed as a mere high-tech bubble. Although these stylized facts suggest that behavioral relationships linking investment and leverage based on historical data should be viewed with caution, the paper presented some limited macroeconomic time-series evidence, which, consistent with firm panel-data evidence reported in other papers, suggests that high leverage can have substantial negative effects on corporate investment.

Most recent forecasts, including the IMF's World Economic Outlook, assume that real GDP growth in the euro area will stage a recovery in the second half of 2003 , reverting back to potential growth in 2004, with the reversion to potential growth underpinned by an acceleration in investment growth. The implicit assumption in these forecasts is that corporate balance sheet restructuring will have largely run its course in 2003. More generally, this benign view on euro-area corporate investment prospects appears to count on several presumptions to prevail: (1) The downward slide in equity valuations since 2000 will come to a stop, or may even reverse as market perceptions of corporations' future growth and investment opportunities in the euro area stabilize or improve. (2) During 2003, corporate financing gaps will have moved back to historical norms and there will be little pressure for corporate financing gaps to undershoot markedly their historical norms. (3) There is only a limited capital investment overhang in the euro area because capacity utilization rates in manufacturing have remained close to their longer-run historical average. (4) Corporate governance problems and financial sector fragilities are unlikely to constrain external financing of the area's corporations. And (5) the level of user cost of capital favors a pickup in investment. For example, the November 2002 Consensus Forecasts suggest that ten-year expected real interest rates in Germany, France, and Italy average $23 / 4$ percent (ex-post longterm real interest rates in Germany during 1980-2001 stood at about 43/4 percent). 
An alternative and less benign view would be, however, that balance sheet restructuring will continue to weigh on corporations' investment plans. ${ }^{21}$ The case for a less upbeat view on the area's corporate investment outlook from the balance sheet perspective rests on the following points: (1) The level of the area's equity valuations remain a downside risk. While there is obviously no confident pronouncement possible on the future direction of equity valuations, there are reasons for caution. At current valuations, the area's corporate sector's equity would still be valued at some 20 percent of GDP above 1995 levels (Table 1). Moreover, long-run time series on equity valuations suggest that downward adjustments in equity valuations tend to be protracted and tend to undershoot longer-term averages. (2) Expected profitability growth has continued to deteriorate through end-2002; and, contrasting with U.S. developments, there is little evidence pointing to a significant secular pickup in the area's productivity growth. (3) While the area's corporate financing gap for capital investment is approaching its historical norm, the re-balancing of internal funds and capital spending has been relatively slow compared with developments in the United States and may continue to constrain capital spending, particularly if the corporate financing gap undershoots to normalize leverage levels as suggested by this paper's regression results. (4) Lingering concerns about the effectiveness of corporate governance following the bursting of the stock market bubble could have lowered targeted leverage ratios. And (5), as a legacy of the financial asset acquisition binge during the second half of the 1990s, the area's corporate sector may face additional adjustment pressures owing to a possible "financial investment overhang" and the risk of holding losses on some of these investments (which mainly represent equity investments) owing to further equity market declines or, perhaps more pertinently, a marked appreciation of the euro against the background of unhedged exchange rate risk. ${ }^{22}$

21 The March 2003 Consensus Forecasts for the euro area suggest that there is little uncertainty among forecasters that the benign view will prevail - the standard deviations for the sampled real GDP and investment growth forecasts in 2004 are relatively small (in the case of the investment growth forecast, the standard deviations are significantly smaller for the euro area than for the U.S. and the U.K.).

${ }^{22}$ There appears to be precious little information available on exchange rate risk exposures of the area's non-financial corporations arising from the FDI and portfolio investment outflows that accompanied the euro's depreciation against the U.S. dollar. But data from the U.S. Treasury International Capital (TIC) reporting system suggest that portfolio flows from the euro area to the U.S. have been large during the U.S. dollar's appreciation phase; and a survey of financial risk management by U.S. non-financial corporations highlights that at least U.S. corporates tend to hedge only a small fraction of their total foreign currency exposures and that the majority of hedges is short-dated (see Bodnar and Marston (1988)). 


\section{References}

Benito, Andrew, and Garry Young, 2002, "Financial Pressure and Balance Sheet Adjustment by U.K. Firms," Working Paper No. 168, Bank of England.

Blanchard, Olivier, Rhee, Changyong, and Lawrence Summers, 1993, "The Stock Market, Profit, and Investment," Quarterly Journal of Economics, Vol. 108, pp. 115-136.

Bodnar, Gordon M., and Richard C. Marston, 1998, "1998 Survey of Financial Risk Management by U.S. Non-Financial Firms," George Weiss Center for International Financial Research, Wharton School, and CIBC World Markets.

Davis, E. Philip, 2003, "Comparing Bear Markets-1973 and 2000," National Institute Economic Review, No. 183, pp. 78-89.

European Central Bank, 2002, Report on Financial Structures (Frankfurt).

Graham, John, and Campbell Harvey, 2002, "How Do CFOs Make Capital Budgeting and Capital Structure Decisions?" Journal of Applied Corporate Finance, Vol. 15, pp. 8-23.

Hall, Simon, and Anne Vila Wetherilt, 2002, "The Role of Corporate Balance Sheets and Bank Lending Policies in a Financial Accelerator Framework," Bank of England Working Paper No. 166.

Hovakimian, Armen, Opler, Tim, and Sheridan Titman, 2002, "The Capital Structure Choice: New Evidence for a Dynamic Trade-Off Model," Journal of Applied Corporate Finance, Vol. 15, pp. 24-30.

Hubbard, Glenn, 1998, “Capital-Market Imperfections and Investment," Journal of Economic Literature, pp. 193-225.

International Monetary Fund, 2000, World Economic Outlook, May 2000 (Washington).

International Monetary Fund, 2003, World Economic Outlook, April 2003 (Washington).

Meyers, Stewart C., 1984, "The Capital Structure Puzzle," Journal of Finance, Vol. 39, pp. 575-92.

Miller, Merton H., 1991, "Leverage," Journal of Finance, Vol. 46, pp. 479-88.

Modgiliani, Franco, and Merton H. Miller, 1958, "The Cost of Capital, Corporation Finance, and the Theory of Investment," American Economic Review, Vol. 48, pp. 261-97. 
Rajan, Rahuram G., and Luigi Zingales, 1995, "What Do We Know About Capital Structure? Some Evidence from International Data," Journal of Finance, pp. 1421-1460.

Taggart, Robert A., 1985, "Secular Patterns in the Financing of U.S. Corporations," in: Corporate Capital Structures in the United States, edited by Benjamin M. Friedman, pp. 13-75 (University of Chicago Press).

Vermeulen, Philip, 2002, "Business Fixed Investment: Evidence of a Financial Accelerator in Europe," Oxford Bulletin of Economics and Statistics, Vol. 64, pp. 213-31. 